\title{
THE ROLE OF CORPORATE ZAKAT ON OPTIMAL CAPITAL STRUCTURE POLICY: EVIDENCE FROM MALAYSIAN FIRMS
}

\author{
Abrapuspa Ghani Talattov ${ }^{1}$ \\ Nur Azura Sanusi ${ }^{2}$ \\ Suhal Kusairi ${ }^{3}$ \\ Abu Hassan Shaari ${ }^{4}$
}

\begin{abstract}
In the finance literature, the relationship between capital structure and firm value has been extensively investigated, both theoretically and empirically. The main issue on corporate finance is how firms dealing with the important decision of capital structure. In this study, a model of capital structure is formulated in which corporate tax and zakat payment exist by firms into the consideration of combination of debt and equity. The theoretical model as shown by comparative statics prove the implication which is negatively relationship between leverage of the firm and the corporate zakat payment. Meanwhile, the empirical evidence reveals several implication as follows, (1) tax deduction reduces the current liability item relative to the firms that prefer equity financing, (2) the significant of zakat is consistent with the theoretical model that zakat would encourage firm to issue more equity than debt, (3) the strong significant relationship between return on assets with the leverage are the leading indicator of capital structure in all models.
\end{abstract}

Keywords: Capital structure, Corporate tax, Zakat

JEL Classification: C33, G32, H2

1 School of Social \& Economic Development, Universiti M alaysia Terengganu; researcher at Institute for Development of Economics \& Finance - INDEF, Jakarta.

Email: abra.undip@gmail.com

2 School of Social \& Economic Development,Universiti M alaysia Terengganu; Email: nurazura@umt.edu.my

3 School of Social \& Economic Development, Universiti M alaysia Terengganu; Email: suhal@umt.edu.my

4 School of Economics, Universiti Kebangsaan M alaysia; Email: ahshaari@yahoo.com 


\section{INTRODUCTION}

In the finance literature, the relationship between capital structure and firm value has been extensively investigated, both theoretically and empirically. The main issue on corporate finance is how firms dealing with the important decision of capital structure. How ever, as Ahmad et al. (2012) stated that capital structure decisions represent an important financial decision of a business organization apart from investment decisions. It is important since capital structure involves the cost of capital and long term implications for the firms.

According to Datta et al. (2013), the term of capital structure is used to represent the proportional relationship between debt and equity. Capital structure refers to the way a corporation finances its assets through some combination of equity, debt, or hybrid securities. In addition, Gleason et al. (2000) appointed that the utilization of different levels of debt and equity in the firm's capital structure is one such firm-specific strategy used by managers in the way for improved performance. Hence, most firms have strived to achieve an optimal capital structure in order to minimize the cost of capital or to maximize the firm value, thereby improving its competitive advantage in the marketplace through a mixture of debt and equity financing. Thus, selecting the right type of debt is an equally important issue as opting for an appropriate debt to equity ratio.

Discussion of optimal capital structure started by Scott (1976) and then Bradley et al. (1984). Both papers tried to elaborate optimal capital structure with comparative statics and simulation models. However, Scott (1976) attested the positive impact of the liquidation value of the firm's assets, the corporate tax rate, and the size of the firm to the optimal capital structure. While, Bradley at al. (1984) have developed a model that synthesizes the modern balancing theory of optimal capital structure. Their model incorporate positive personal taxes on equity and on bond income, expected costs of financial distress, and positive non-debt tax shieds. Previously, Miller (1977) has produced the formula to calculate the gains from using leverage by synthesizing differences in corporate income tax rates as well as personal tax rates on interest, dividends, and capital gain.

Later, Haugen and Senbet (1988) proposed bankruptcy cost and agency cost as a significant contribution to the optimal capital 
structure. The majority of researches on corporate capital structure focuses on searching for an optimal capital structure, which derives from the trade-off theory. Optimums normally require a trade-off, for example, between the tax advantages of borrowed money and the costs of financial distress when the firm funds it has borrowed too much. Numerous factors have profound impacts on the firm's choice of capital structure. So, in order to develop an optimal capital structure, finance managers have to consider those factors that arise from the market imperfections such as corporate taxes, costs of financial distress, and agency costs.

As already mentioned before, the financial managers have to ensure the fully utilization of corporate taxes to shield taxable income as much as possible. By doing so, they could enable firms to avoid a certain amount of corporate taxes. As a result, it will make these firms better off as they have more money to pay for investors and hence enhance their own value. On the other hand, as Rasiah and Kim (2011) stressed that firms should also make sure that the interest tax shield of debts is equivalent to the costs of financial distress. More importantly, since most of the financial distress costs are hard to measure accurately and whereby it may bring on other significant costs that would cut down the value of firms. Therefore, the need of balance the tax benefits of debt against the cost of financial distress is indispensable for the diminishing of these momentous costs.

Meanwhile, there is an alternative for tax payments which is zakat payment. Since zakat payment is an alternative for tax payments in Malaysia, it is interesting to see how does the presence of zakat have influence to capital structure decisions. Until now, the Malaysian government has provided incentives to promote zakat payment for companies. According to Badawi (2004), it had been announced that any zakat which is paid by the company to the State Islamic Religious Councils (SIRCs) will be granted as an allowable deduction in the computation of the corporate tax. However, the amount of deduction is limited to 2.5 per cent of the aggregate income (Badawi, 2004; Bakar, 2007; Othman, 2013).

However, Booth et al. (2001) claimed that the test of capital structure policy should be consider some characteristics such as institutional, cultural, and economic factors that are significantly 
different among countries. Further, given the unique system of Malaysian business in terms of the existence of corporate zakat, an examination the role of zakat on capital structure policy in Malaysia should be valuable in yielding new insights on capital structure theory. Further, this study tries to develop the model of Islamic capital structure theory by take into account the zakat payment as factor that could be affect capital structure policy. Despite many theories may explain the conventional capital structure theory. This study will focus on the introduction of zakat in the conventional static trade-off theory developed by Miller (1977) and Bradley et al. (1984).

\section{LITERATURE REVIEW}

\subsection{Discourse of Capital Structure Theory}

The capital structure as the most important parameter in evaluating companies performance must be considered by manager. Even, management has to afford to determine the capital structure due to identify an ideal combination of financial sources in each company, in order to increase the firm value. Choosing an ideal capital's structure means how to decrease firm's costs and increase its value in the market.

The debate over the decision about the optimal capital structure of the company has been ignited by the seminal work of Modigliani \& Miller (1958). They have illustrated that without market imperfections of the perfect capital market, capital structure decisions of the company have failed to make an impact on the value of the company. In other words about the financing mix, the company does not have to worry about it. Since then, a large number of competition theory and empirical research from around the world appeared, introducing capital market imperfections.

Since then, a convolute of academic papers emerged testing the validity of the notion of the Modigliani \& Miller's (1958) irrelevance theory. In essence, the subsequent capital structure theories have in common that include certain market imperfections, which are considered to be the driving force for firm value enhancement. In their corrected version of the classic MM's propositions, Modigliani and Miller (1963) showed that when corporate tax is taken into 
consideration, the firm value becomes an increasing function of debt. Debt financing is viewed as more advantageous than equity because using more debt reduces the expected tax liability and increases the after tax cash flow.

Furthermore, in corporate finance there exists a large body of literature that examines the financing behaviour of firms, reflected by their capital structure. However, based on Kraus and Litzenberger (1973), research in the capital structure field is dominated by three theories: trade-off, pecking order and agency costs theory. Each theory presents a different explanation of corporate financing. The trade-off theory incorporates two imperfections, taxes and bankruptcy costs in the theoretical model in order to determine optimal capital structure decision of firms (Modigliani \& Miller, 1963; Kraus \& Litzenberger, 1973). The notion of this theory is basically that firms need to weight the benefits of debt taxes with the costs of bankruptcy.

Meanwhile, the pecking order theory assumes hierarchal financing decisions where firms depend first on internal sources of financing and, if these are less than the investment requirements, the firm seeks external financing from debt as a second source, then equity as the last resort (Myers, 1984). Moreover, the agency costs theory assumes that debt presents fixed obligations (debt interests and principals to pay) that have to be met by the firm. These obligations are assumed to take over the firm's free cash flow (if exists), therefore prevents managers from over consuming the firm's financial resources (Jensen \& M eckling, 1976; M yers, 1977).

As stressed by Myers (2001) that the three theories are "conditional" in a sense that each works out under its own assumptions and propositions. That is, none of the three theories can give a complete picture of the practice of capital structure. This means that firms can pursue capital structure strategies that are conditional as well. That means that when the business conditions change, the financing decisions and strategies may change, moving from one theory to another.

However, despite research in the capital structure field has been dominated by three main theories: the trade-off theory, pecking order 
theory, and agency costs theory. Further, this study will focus on the trade-off theory only.

Kraus and Litzenberger (1973) formulated the classical version of trade-off theory. They stated that the optimal leverage level reflects a trade-off between the tax shield benefits of debt and the bankruptcy costs. The two proponents of the theory showed that, for a specific period (one year, for instance), the market value of a levered firm is equal to the market value of an unlevered firm, to which is added the present value of the tax shield of debt less the present value of bankruptcy costs. However, corporate tax and bankruptcy costs are the central market frictions on which the tax-based trade-off theory is established.

As discussed previously, the static trade-off theory emerged in the streamline of the path-breaking irrelevance theorem. Static tradeoff theory, focus on the repayment and costs of issuing debt, predicts that an attractive target debt ratio is to make the paramount value of the company. The best point can be accomplished when the marginal value of the payback is linked with debt concerns exactly offsets the rise in the present value of the costs correlated by handing out more debt, as M yers (2001) point out. M oreover, the main benefit of debt is the tax deductibility of interest payments. The tax deduction of corporate interest payments supports the application of debt. Under the trade-off theory, Bradley et al. (1984) point out that the firms have a target debt ratio and try to move towards this target. The target leverage ratio occurs when the marginal benefit of tax equals the marginal cost of an additional unit of debt.

Furthermore, the static trade-off theory explained that each firm has a well-defined optimal capital structure, which balances the benefits and costs associated with debt financing. The main benefits of debt include (i) tax deductibility gained by tax paying firms (Modigliani \& Miller, 1963), and (ii) advantages of using debt to mitigate the agency costs of equity and the free cash flow problem (e.g. Jensen \& M eckling, 1976; Jensen, 1986). The costs of debt can be identified as (i) non-debt tax shields (DeAngelo \& Masulis, 1980), and (ii) agency costs of debt due to suboptimal investment behaviour (Jensen \& Meckling, 1976), or underinvestment problem (Myers, 1977). 
However, the determination of debt also be influenced by the existence of other non-debt tax shields such as depreciation, allow ances for research and development expenses and investment tax credit. According to DeAnglo and M asulis (1980), indicated that firms with tax deductions for depreciation and investment tax credits can consider these deductions as a substitute for the tax shield. Then, they revealed that there is a negative connection between debt and nondebt tax shield.

As stressed earlier, the most significant reason that prompt firms to raise debts are due to the tax shield that results from the tax savings generated by making interest payments on debt. As a result, by using debt, estimated tax liability of firms could be deducted and thus increase its after-tax cash flow, causing more lucrative business to utilize higher level of debt for the sake of increasing their debt tax shield. Nonetheless, debt financing not only produce benefit, but also yield costs such as interest, agency costs, bankruptcy cost, etc. Therefore, firms have to consider costs of both debt and equity in order to maximize its value.

Besides, a firm can maximize its value by issuing as much debts as possible, but if the firm is using too much debt in its capital structure, there is a higher possibility that the firm cannot meet its interest and principal payment and will default on its debt obligations. More specifically, a firm that has difficulty and trouble meeting its debt obligations is in financial distress. However, the static trade-off theory incorporates the bankruptcy and agency costs along with the tax saving benefits in the balance.

\subsection{The Presence of Zakat in Malaysian Business}

As already discussed previously, the most significant reason that stimulate firms to raise debts are due to the tax. Interestingly, there is an alternative for corporate tax payment namely zakat payment (Sanusi, 2014). Until now, the discourse on zakat generally and zakat payment in the business environment in particular has been steadily expanding. But, still few research which considering zakat payment as factor that could influence capital structure decision (such as Barakat \& Rao, 2003; Sanusi, 2014). 
A previous study by Barakat and Rao (2003, p. 18), have tried to consider the existence of zakat as "charity" in Arab's firms. They test the interaction between zakat and corporate tax in order to find out its effect on the capital structure decision in Arab countries. However, they found that the effective tax rate together with zakat generates debt financing in Arab countries. Meanwhile, the fundamental work by Sanusi (2014) reveals that the leverage ratio for firms that pay zakat is smaller than the firms that only pay tax. In addition, Sanusi (2014) also claims that zakat able to increase the equity financing by reducing the use of leverage. However, as Sanusi (2014) question whether the existence of zakat triger an advantages or a disadvantages instead for the utilization of debt financing is unclear.

However, since Malaysia is the few country in the world, where zakat payments are deducted from the income tax. This study will designate Malaysia as base for construct Islamic capital structure. In 2005, M alaysian government was announced that any corporate zakat paid to State Islamic Religious Councils (SIRCs) will be considered as an allowable deduction. Moreover, Bakar (2007) asserted that more Malaysian companies are becoming aware and more interested in fulfilling their zakat obligation.

According to Bakar (2007), all aspects pertaining to the administration of zakat are handled by the states through their respective State Islamic Religious Councils (SIRCs). Zakat administration comes under the jurisdiction of the respective state or the prerogative of its ruler (sultan). The only exception is the Federal Territory, where the zakat law and administration are governed by the federal government. Accordingly, each state formulates its own policy on zakat matters, including the method of collection, disbursement policy, administrative aspects, execution, and the degree of enforcement.

Meanwhile, the basic principle of zakat on corporate wealth is based on merchandise goods ('urud al-tijarah), namely, anything obtained for the purpose of trading to gain a profit. The wealth becomes zakatable once it exceeds the nisab, which is calculated as the equivalent monetary value of 85 grams of gold. Once this requirement is met, zakat needs to be paid each year at the rate of 2.5 percent. Moreover, refering to the section 44(11A) of the Income Tax 
Act 1967, in 2005 the Government had allowed the amount of zakat paid by a company is to be treated as deduction of up to $2.5 \%$ of the aggregate income (Badawi, 2005; Othman, 2013; Bakar, 2007).

\subsection{Determinants of Optimal Capital Structure}

As discussed before, the optimal capital structure would consider several factors such as corporate tax, and cost of financial distress. Nonetheless, previous empirical studies also consider other factors that expected have influence to capital structure decision. Therefore, further session will discusses additional factors and how those factors could effect the capital structure. As Shyam-Sunder \& Myers (1999) stated that the theory of capital structure has been dominated by the search for optimal capital structure. Optimums normally require a trade-off, for example between the tax advantages of debt and the costs of financial distress.

\subsubsection{Corporate Tax}

According to Modigliani and Miller (1963), companies should aim towards entire debt financing due to tax deductions associated with interest payments on debt. This effect encourages the use of debt by firms as more debt increases the after-tax earnings to the owner. Thus, the tax benefits of leverage should increase the value of reaching and maintaining the leverage target for underleveraged firms.

As Byoun (2008) claimed that defining tax variables is difficult for individual firms, because the marginal value of the tax shield should be either zero or positive for all firms. However, Byoun (2008) calculated an average tax rate from data on both earnings before and earnings after tax for several developing countries, except Malaysia, which he used earnings before tax and taxed paid, because of the availability of data. Interestingly, Byoun (2008) found that the sign on the average tax rate is generally negative to leverage ratio.

Meanwhile, Negash (2002) calculated effective tax rates (ETRs) and marginal tax rates (M TRs) as proxy of the tax variable. Effective tax rate is defines as the ratio of actual tax paid as reported in the cash flow statement and earnings before interest and taxes (EBIT). While, marginal tax rates (MTRs) computed as the ratio of change in actual 
tax paid to change in EBIT. However, Negash (2002) also found that the coefficients of the two tax proxies (ETRs \& MTRs) are negative to leverage. In addition, Negash also reveal that ETRs can explain extent of leverage better than MTRs.

More recently, Sanusi (2014) utilized ratio of the total corporate tax over the total profit/loss before tax (EBIT). When the corporate tax rate is raised, firms will substitute debt for equity financing. Firms subject to lower corporate tax rates will employ more debt in their capital structure (holding earnings constant). However, her empirical test shows that corporate tax is not significant to leverage decision.

Therefore, in line with the previous work, this study will utilize effective corporate tax rate to evaluate the effect of the value of tax shields on the adjustment decision. Thus, the proxy used is corporate tax divided by total earnings before taxes. However, this study hypothesize that a higher corporate tax rate leads firms to employ more debt in capital structure, based on static trade-off theory.

In a nutshell, there are several other studies on the impact of corporate taxation on financing decisions such as by Bradley et al. (1984), Titman \& Wessels (1988), Booth et al. (2001), \& Negash (2002) do not consistently find a positive relation between tax status and financial leverage. On the other hand, MacKie-Mason (1990), Givoly et al. (1992), Graham (1996), and Graham et al. (1998) provide empirical evidence that taxes influence capital structure decisions.

\subsubsection{Corporate Zakat}

Since zakat payment which is paid by firms granted as an allowable deduction in the computation of the corporate tax, thus zakat payment practically treated as non-debt tax shield, likes depreciation deductions on income statement. Therefore, according to DeAngelo \& Masulis (1980), if non-debt tax shields exist, firms are likely not to use fully debt tax shields. In other words, firms with large non-debt tax shields have a lower incentive to use debt from a tax shield point of view, and thus may use less debt.

However, as the testable implication of comparative statics in Islamic capital structure modeling, the optimal level of debt is inversely related to the corporate zakat payment. It's also related to previous study such as Sanusi (2014) that argue the effect of zakat to the 
capital structure choices depends on the working capital. Therefore, it is expected firms with high debt financing will have low current liability and large working capital and zakat payment. Thus, zakat will encourage the firm to use equity financing. Moreover, to see the effect of zakat payments to capital structure decision, the proxy used is zakat payment divided by total earnings before taxes and zakat.

\subsubsection{Size}

Size is a factor that can be seen in almost every study investigating capital structure. Huang and Song (2006) support the idea that size can be used as a proxy for information asymmetries; the larger the firm, the more information is provided to outside investors. Alternatively, Rajan and Zingales (1995) state that size is likely to have an inverse relationship with the probability of default, thus enabling large firms to obtain larger amounts of leverage. According to Frank \& Goyal (2009), firms that are mature and large in terms of assets tend to have higher leverage. Their empirical evidence is consistent with the trade-off theory because large, more diversified companies face lower default risk and older companies face lower debt-related agency costs due to better reputations in debt markets.

However, a positive relationship between size and leverage is expected as the hypotheses in this study. Such a relationship is indeed reported by the majority of relevant papers (e.g. Booth et al., 2001; Guney et al., 2011; Hirota, 1999; Psillaki \& Daskalakis, 2008). However, in this study the proxy chosen to measure size is the natural logarithm of sales or turnover. This measurement is supported by previous studies such as Rajan and Zingales (1995), Song (2005), Booth et al. (2001), Voutsinas and Werner (2011), Sanusi (2014), and Shahid et al. (2014).

\subsubsection{Bankruptcy Cost}

Theoretically, a firm can maximize its value by issuing as much debt as possible, but if the firm is using too much debt in its capital structure, there is a higher possibility that the firm cannot meet its interest and principal payment and will default on its debt obligations. More specifically, a firm that has difficulty and trouble meeting its debt obligations is in financial distress. However, the static trade-off theory incorporates the bankruptcy and agency costs along with the tax 
saving benefits in the balance. Moreover, many literatures indicate that the existence of bankruptcy costs is to induce firms to minimize business risk by decreasing debt levels in their capital structures. The tax shield-bankruptcy costs theory of optimal capital structure determines a firm's optimal capital leverage as a function of the distribution of future earnings, business risk, default costs, and taxes (Castanias, 1983).

However, measuring the bankruptcy costs is a difficult task because one should select a measure that relies on expectations concerning a firm's profitability as compared to that of the market and that also takes into account the specific nature of the firm's assets. However, as suggested by Rajan and Zingales (1995), the measurement of risk that equity holders will not be able to make fixed payments and will have to give up control is the coverage ratio, namely the ratio of earnings before interest and taxes (EBIT) to interest expense.

Meanwhile, according to Besley \& Brigham (2003), firms also give considerable weight to financial strength indicator such as the times-interest-earned (TIE) ratio, which is computed by dividing earnings before interest and taxes by interest expense. The TIE ratio provides an indication of how well the firm can cover its interest payments with operating income (EBIT). The lower this ratio, the higher the probability that a firm will default on its debt and experience financial distress, perhaps even be forced into bankruptcy.

Furthermore, the proxy of this study in line with the previous study such as Sanusi (2014). However, as discussed earlier that firms operating in business with volatile earnings have high possibility to default on interest payments. Therefore, firms with a volatile earnings would employ less debt. The negative relationship is supported by empirical evidence, among others (see for examples, Castanias, 1983; Bradley et al., 1984; Titman \& Wessels, 1988; Booth et al., 2001; Fama \& French, 2002; De Jong et al., 2008; Sheikh \& Wang, 2011).

Despite most empirical studies that find negative relationship between business risk and leverage, a recent study by Dawood et al. (2011) contradicts it by depicting a positive relationship between leverage and business risk on Egyptian listed firms. According to them this is due to pure cultural reasons among investors in Egypt. Once the 
business risk of a firm is perceived to increase, investors are expected to avoid purchasing its shares, making it increasingly difficult for the firm to raise equity financing from the stock market. As a result, the firm is forced to raise financing via debt thus results in a positive relationship between debt and business risk.

\subsubsection{Profitability}

In line with previous studies analysing determinants of the capital structure choice, the measure of profitability is earnings before interest payments and income taxes (EBIT) divided by total assets or usually called as return on assets (ROA). As Overesch \& Voeller (2008) noted that utilizing this measurement may control variations in companies' profitability and also avoid endogeneity problems.

Byoun (2008) hypotheses that a firm with higher earning with higher earnings could prefer to operate with either lower or higher leverage. Lower leverage might occur as higher retained earnings mechanically reduce leverage, or if the firm limits leverage to protect the franchise responsible for producing these high earnings. Higher leverage might reflect the firm's ability to meet debt payments out of its relatively high earnings cash flow.

Voutsinas and Werner (2011) used the earnings before interest and debt to total assets ratio as the proxy for profitability. In addition, they also add the retained earning to total assets ratio as a robustness measure as well as a factor that will directly test for the validity of the pecking order hypothesis. Their study evince that profitability was negatively related to leverage. It is accordance with the pecking order hypothesis that firms indeed seem to prefer internal to external finance. Some other studies that also find inversely related between profitability and level of debt are De Jong et al. (2008), Qian et al. (2009), De Jong et al. (2011), Kayo \& Kimura (2011), Guney et al. (2011), Tongkong (2012), and Mateev et al. (2013). However, a positive relationship would confirm the trade-off theory and a negative relationship would confirm the pecking order theory.

\subsubsection{Tangible Assets}

As Gaud et al. (2005) stated that tangible assets are likely to have an impact on the borrowing decisions of a firm because they are 
less subject to information asymmetries and usually they have a greater value than intangible assets in case of bankruptcy. Additionally, the moral hazard risks are reduced when the firm offers tangible assets as collateral, because this constitutes a positive signal to the creditors who can request the selling of these assets in the case of default. As such, tangible assets constitute a good collateral for loans. According to Scott (1976), a firm can increase the value of equity by issuing collateralised debt when the current creditors do not have such guarantee. Hence, firms have an incentive to do so, and one would expect a positive relation between the importance of tangible assets and the degree of leverage.

Almeida and Campello (2007) showed that tangibility is particularly important when the firm is financially constrained and thus has restricted access to external resources. However, according to the results of Almeida and Campello (2007), tangibility is less important when firms are unconstrained. In addition, Voutsinas and Werner (2011) used the ratio of total tangible fixed assets to total assets to account for the asset tangibility factor. Their result show that the tangibility of assets factor is positively correlated with leverage. However, many studies indicate a positive relationship between the tangibility and leverage (see Almeida \& Campello, 2007; De Jong et al., 2008; Qian et al., 2009; De Jong et al., 2011; Kayo \& Kimura, 2011; Guney et al., 2011; and M ateev et al., 2013).

\section{METHODOLOGY}

\subsection{Theoretical Model}

As stressed previously, capital structure of the firm is an important thing that must be decided by the managers, as it will ultimately related to the firm value. How does a manager determines the composition of capital structure to be an important task. However, further discussion will be focused on develop of theoretical model that consider the objectives of the study as pointed out earlier, especially in terms of the influence of zakat on capital structure decision.

Furthermore, the theoretical model to develop the relationship between zakat and firm's capital structure is adopted from Bradley et 
al. (1984). Several modifications will be introduced. The modifications involved the construction of a static capital structure model in the presence of zakat. In addition, the modifications also incorporated the modes of Islamic debt and equity financings. The model captures the essence of the tax advantage and bankruptcy costs trade-off models of Kraus and Litzenberger (1973) and Scott (1976); the agency costs of debt arguments of Jensen and M eckling (1976) and M yers (1977); the potential loss of non-debt tax shields in non-default states in DeAngelo and Masulis (1980); the differential personal tax rates between income from stocks and bonds in Miller (1977), and the extensions of Miller's model by DeAngelo and Masulis (1980), and Bradley et al. (1984).

However, the model involves zakat payment as Islamic instrument due to modeling of Islamic capital structure. In a nutshell, the model will treat zakat as non-tax shield that expected has effect to finance decision. Regarding the purpose of developing Islamic capital structure, this study employing the original model from Bradley et al. (1984), then extends that model with considering zakat payment. More importantly, to develop a model that represents the current state in the theory of optimal capital structure, the following assumptions have to be fulfilled:

1. Investors are risk-neutral.

2. Investors face a progressive tax rate on returns from bonds, $t_{p b}$, while the firm faces a constant corporate tax rate, $t_{c}$, and also faces a constant zakat rate, $z_{c}$.

3. Corporate and personal taxes are based on end-of-period wealth; consequently, debt payments (interest \& principle) are fully deductible in calculating the firm's end-of-period tax bill, and are fully taxable at the level of the individual bondholder.

4. Equity returns (dividends $\&$ capital gains) are taxed at a constant rate, $t_{p s}$.

5. There exist non-debt tax shield, such as accelerated depreciation and investment tax credits, that reduce the firm's end-of-period tax liability.

6. Negative tax bills (unused tax credits) are not transferrable (saleable) either through time or across firms. 
7. The firm will incur various costs associated with financial distress should it fail to meet, in full, the end-of-period payment promised to its bondholders.

8. The firm's end-of-period value before taxes and debt payments, $\tilde{X}$, is a random variable. If the firm fails to meet the debt obligation to its bondholder, $\hat{Y}$, the costs associated with financial distress will reduce the value of the firm by a constant fraction $k$.

Furthermore, under the above assumptions of the model, the cash flow of debt and equity after corporate tax and zakat payment then the uncertain end-of-period pretax returns to the firm's stockholders and bondholders can be written as follows:

$$
\begin{aligned}
& \tilde{Y}_{s}=\left\{\begin{array}{cl}
(\tilde{X}-\hat{\mathrm{Y}})\left(1-t_{c}\right)+\phi-z_{c}(\tilde{X}), & \widetilde{\mathrm{X}} \geq \hat{\mathrm{Y}}+\phi / \mathrm{t}_{\mathrm{c}} \\
\tilde{X}-\hat{\mathrm{Y}}-z_{c}(\tilde{X}), & \hat{\mathrm{Y}} \leq \widetilde{\mathrm{X}}<\hat{\mathrm{Y}}+\phi / \mathrm{t}_{\mathrm{c}} \\
0, & \widetilde{\mathrm{X}}<\hat{\mathrm{Y}}
\end{array}\right. \\
& \tilde{Y}_{b}=\left\{\begin{array}{cl}
\hat{\mathrm{Y}}, & 0 \leq \hat{\mathrm{Y}}<\hat{\mathrm{Y}} \\
\widetilde{\mathrm{X}}(1-\mathrm{k})-\mathrm{z}_{\mathrm{c}}(\widetilde{\mathrm{X}}), & \widetilde{\mathrm{X}}<0 \\
0, &
\end{array}\right.
\end{aligned}
$$

where:

$\widetilde{\mathrm{Y}}_{\mathrm{b}}, \widetilde{\mathrm{Y}}_{\mathrm{s}}=$ the gross end-of-period returns to bondholders and stockholders, respectively,

$\widetilde{\mathrm{X}} \quad=$ the firm's end-of-period value before taxes and debt payments,

$\hat{Y} \quad=$ the total end-of-period promised payment to bondholders,

$\phi \quad=$ the total after-tax value of the non-debt shields if they are fully utilized at the end-of-period,

$\mathrm{t}_{\mathrm{c}} \quad=$ corporate tax rate,

$\mathrm{z}_{\mathrm{c}}=$ corporate zakat rate,

$\mathrm{k}=$ costs of financial distress of end-of-period value of the firm.

The model modification above has been incorporate zakat payment as non-tax shield. Zakat payment calculated based on firm's earning before taxes and debt payments. More spesifically, Equation 
(1) shows that if pre-tax earnings are large enough for the firm to fully utilize the non-debt tax shield $\left(\phi / t_{c}\right)$, then the gross end-of-period return to stockholders is $\left(\tilde{X}-\hat{Y}-\phi / t_{c}\right)\left(1-t_{c}\right)+\phi / t_{c}-z_{c}(\tilde{X})=$ $(\tilde{X}-\hat{Y})\left(1-t_{c}\right)+\phi-z_{c}(\tilde{X})$. Then, if the firm's pre-tax earnings are such that $\tilde{X}-\hat{Y}-\phi / t_{c}<0$, the firm will pay no tax but still pay zakat, and Assumption 6 implies that the end-of-period return to stockholders is $\tilde{X}-\hat{Y}-z_{c}(\tilde{X})$. Meanwhile, the end-of-period pre-tax return to bondholders in Equation (2) follows from Assumption 8 and the fact that bondholders have limited liability in the event that the firm's end-of-period value $\tilde{X}$ is negative.

According to Assumption 1, that of risk neutrality, Equations (1) and (2) provide the following beginning-of-period market value of the firm's stocks (S) and bonds (B):

$$
\begin{gathered}
S=E\left(\tilde{Y}_{s}\right) / E\left(\tilde{r}_{s}\right)=\frac{1-t_{p s}}{r_{o}} \\
{\left[\int_{\hat{Y}+\phi / t_{c}}^{\infty}\left[(\tilde{X}-\hat{Y})\left(1-t_{c}\right)+\phi-z_{c}(\tilde{X})\right] f(\tilde{X}) d \tilde{X}+\int_{\hat{Y}}^{\hat{Y}+\phi / t_{c}}(\tilde{X}-\right.} \\
\left.\hat{Y})-z_{c}(\tilde{X}) f(\tilde{X}) d \tilde{X}\right] \\
B=E\left(\tilde{Y}_{b}\right) / E\left(\tilde{r}_{b}\right)=\frac{1-t_{p b}}{r_{o}} \\
{\left[\int_{\hat{Y}}^{\infty} \hat{Y} f(\tilde{X}) d(\tilde{X})+\int_{0}^{\hat{Y}} \tilde{X}(1-k)-z_{c}(\tilde{X}) f(\tilde{X}) d(\tilde{X})\right]}
\end{gathered}
$$

where:

S, B

$\mathrm{E}\left(\tilde{\mathrm{r}}_{\mathrm{s}}\right), \mathrm{E}\left(\tilde{\mathrm{r}}_{\mathrm{b}}\right) \quad=$ one plus the expected pre-tax rate of return from stocks and bonds, respectively,

$\mathrm{r}_{\mathrm{o}}$

$f(\widetilde{\mathrm{X}})$

$t_{p s}$

$=$ the market value of the firm's stocks and bonds, respectively,

$=$ one plus the rate of return on default-free, taxexempt bonds,

$=$ probability density of $\widetilde{\mathrm{X}}$,

$=$ equity returns (dividends $\&$ capital gains) are taxed at a constant rate, $=$ progressive tax rate on returns from bonds. 
Furthermore, adding Equation (3) and (4) yields the market value of the firm (V):

$$
\begin{aligned}
V=\frac{1}{r_{o}}\left[\left(1-t_{p b}\right)\right. & \int_{0}^{\hat{Y}} \tilde{X}(1-k)-z_{c}(\tilde{X}) f(\tilde{X}) d(\tilde{X}) \\
& +\int_{\hat{Y}}^{\hat{Y}+\phi / t_{c}}\left[\left\{(\tilde{X}-\hat{Y})-z_{c}(\tilde{X})\right\}\left(1-t_{p s}\right)\right. \\
& \left.+\hat{Y}\left(1-t_{p b}\right)\right] f(\tilde{X}) d(\tilde{X}) \\
& +\int_{\hat{Y}+\phi / t_{c}}^{\infty}\left[\left\{(\tilde{X}-\hat{Y})\left(1-t_{c}\right)+\phi-z_{c}(\tilde{X})\right\}\left(1-t_{p s}\right)\right. \\
& \left.\left.+\hat{Y}\left(1-t_{p b}\right)\right] f(\tilde{X}) d(\tilde{X})\right]
\end{aligned}
$$

Equation (5) shows that the value of the firm is equal to the present value of the sum of three expected values (integrals). The first integral represents the situation in which is $\widetilde{\mathrm{X}}$ positive but insufficient to meet its debt obligation. Under this condition, the payment to the firm's bondholders is $\widetilde{\mathrm{X}}$ less total costs of financial distress, $k \widetilde{\mathrm{X}}$, and then less total zakat payment of the firm's end-of-period value before taxes and debt payments $\mathrm{z}_{\mathrm{c}} \widetilde{\mathrm{X}}$. Consistent with the assumption of a wealth tax, the payment to the firm's bondholders, net of costs of financial distress, is subject to the personal tax rate $t_{p b}$.

The second integral represents the states of world in which the firm's end-of-period pre-tax value, $\widetilde{X}$, is greater than its debt obligation ( $(\hat{Y})$ but less than the maximum level of earnings that would result in a zero end-of-period corporate tax bill $\left(\hat{Y}+\phi / t_{c}\right)$. In these states, the firm has no corporate tax bill; however, the payments to bondholders and stockholders are subject to the personal tax rates. Finally, the third integral defines the after-tax cash flows to the firm's securityholders if earnings are sufficient to pay bondholders and to generate a positive corporate tax liability.

Furthermore, the firm's optimal leverage decision involves setting $\hat{Y}$, the end-of-period payment promised to bondholders, such that the market value of the firm is maximized. Differentiating (5) with respect to $\hat{Y}$ yields the first order condition of Equation (6), where $V_{\hat{Y}}$ is 
the partial derivative $\partial \mathrm{V} / \partial \hat{\mathrm{Y}}$.

$$
\begin{aligned}
V_{\hat{\mathrm{Y}}}=\frac{\left(1-t_{p b}\right)}{r_{o}}[ & \left\{-k-z_{c}+\frac{\left(1-t_{p s}\right) z_{c}}{\left(1-t_{p b}\right)}\right\} \hat{\mathrm{Y}} . f(\hat{\mathrm{Y}}) \\
& +\left\{(1-F(\hat{\mathrm{Y}}))\left(1-\frac{\left(1-t_{p s}\right)\left(1-t_{c}\right)}{\left(1-t_{p b}\right)}\right)\right. \\
& \left.\left.-\frac{\left(1-t_{p s}\right)}{\left(1-t_{p b}\right)} t_{c}\left(F\left(\hat{\mathrm{Y}}+\frac{\phi}{t_{c}}\right)-F(\hat{\mathrm{Y}})\right)\right\}\right]
\end{aligned}
$$

where $F$. is the cumulative of probability density function of $\widetilde{X}$.

The first term in Equation (6) represents the marginal net tax advantage of debt, while the second and third terms represent marginal expected leverage-related costs. The optimal leverage involves balancing the net tax advantege of debt against leveragerelated cotsts, non-debt tax shield, and zakat.

Furthermore, in order to know the effect of each variable on capital structure, we can utulize the comparative statics analysis. The comparative statics of the leverage relevancy model can be shown by differentiating the optimally condition (6) with respect to each of the relevant exogenous variables. Differentiating $V_{\hat{Y}}$ in (6) with respect to $z_{c}, k, \phi, t_{p s}$ and $t_{p b}$ yields the following cross-partial derivatives:

$$
\begin{aligned}
& \mathbf{V}_{\hat{Y} \mathbf{Z c}}=\frac{\left[-\left(\mathbf{1}-\mathbf{t}_{\mathbf{p b}}\right)-\left(\mathbf{1}-\mathbf{t}_{\mathbf{p s}}\right)\right] \hat{\mathrm{Y}} . \mathbf{f}(\hat{\mathrm{Y}})}{\mathbf{r}_{\mathbf{o}}}<\mathbf{0} \\
& \mathbf{V}_{\hat{\mathrm{Y}} \mathbf{k}}=\frac{-\left(\mathbf{1}-\mathbf{t}_{\mathbf{p b}}\right) \hat{\mathrm{Y}} \cdot \mathbf{f}(\hat{\mathrm{Y}})}{\mathbf{r}_{\mathbf{o}}}<\mathbf{0} \\
& \mathrm{V}_{\hat{\mathrm{Y}} \phi}=\frac{-\left(1-\mathrm{t}_{\mathrm{ps}}\right) f\left(\hat{\mathrm{Y}}+\frac{\phi}{\mathrm{t}_{\mathrm{c}}}\right)}{\mathrm{r}_{\mathrm{o}}}<0 \\
& \mathrm{~V}_{\hat{\mathrm{Y}} \mathrm{t}_{\mathrm{ps}}}=\frac{\left\{[1-\mathrm{F}(\hat{\mathrm{Y}})]-\mathrm{t}_{\mathrm{c}}\left[1-\mathrm{F}\left(\hat{\mathrm{Y}}+\frac{\phi}{\mathrm{t}_{\mathrm{c}}}\right)\right]\right\}}{\mathrm{r}_{\mathrm{o}}}>\frac{\left(1-\mathrm{t}_{\mathrm{c}}\right)[1-\mathrm{F}(\hat{\mathrm{Y}})]}{\mathrm{r}_{\mathrm{o}}}>\frac{\hat{\mathrm{Y}} \mathrm{f}(\hat{\mathrm{Y}})}{\mathrm{r}_{\mathrm{o}}}>0 \\
& \mathrm{~V}_{\hat{\mathrm{Y}} \mathrm{t}_{\mathrm{pb}}}=\frac{\left(-\mathrm{k}-\mathrm{z}_{\mathrm{c}}\right) \hat{\mathrm{Y}} \cdot \mathrm{f}(\hat{\mathrm{Y}})-[1-\mathrm{F}(\hat{\mathrm{Y}})]}{\mathrm{r}_{\mathrm{o}}}<0
\end{aligned}
$$


The cross-partial derivatives in Equations (7), (8) and (9) are negative. An increase in zakat payment, the cost of financial distress and non-debt tax shields will lead to a reduction in the optimal level of debt. Further, the comparative statics provide the following testable implications:

1. The optimal level of debt is inversely related to the corporate zakat payment.

2. The optimal level of debt is inversely related to the costs of financial distress, which include bankruptcy costs and the agency costs of debt.

3. The optimal level of debt is inversely related to the level of non-debt tax shields.

4. The optimal level of debt is positively related to the personal tax rate on equity.

5. The optimal level of debt is inversely related to the marginal bondholder's tax rate.

However, it is supported by DeAngelo and Masulis (1980), they showed a model of corporate tax and differential personal tax, introducing the factor of "non-debt corporate tax shields", referring to "depreciation deductions or investment tax credits" and "depletion allowances". They argue that non-debt corporate tax shields suggest a unique interior optimum leverage decision for each firm in market equilibrium, no matter whether leverage-related costs are present or not. Based on their model, they predict that leverage of the firm is i) positively related to corporate tax rates; ii) negatively related to marginal bankruptcy costs; and iii) negatively related to the non-debt tax shields.

As alluded to earlier, according to the static trade-off theory of capital structure (also referred to as the tax based theory), optimal capital structure is obtained where the net tax advantage of debt financing balances leverage related costs such as financial distress and bankruptcy. In view of this conventional theory, issuing equity means moving away from the optimum and should therefore be considered bad news.

Furthermore, since there is any alternative for tax payments namely zakat payment. As stressed earlier, the zakat payment is 
expected to influence the capital structure decisions. Moreover, the comparative statics prove the implications which is negatively relationship between leverage of the firm and the corporate zakat payment. In other words, managers tend to react positively to an equity issue as a result of "the zakat payment shield benefit".

\subsection{Sample and Data}

The primary source of data in this research is Bursa Malaysia. This study attempt to examine a panel data (unbalanced) of companies which listed on Main Market of the Bursa Malaysia for 14 firms that pay zakat and corporate tax over 16 years (1998 to 2014). This sample period is able to observe the capital structure due to the effects of fluctuations in economic activity. However, following study by Sanusi (2014) in Malaysia, this study will exclude the heavily regulated industries such as financial and securities companies as their financial characteristics and use of leverage is substantially different from other companies.

\subsection{Method of Analysis and Econometric Specification}

In line with the theoretical models that have been developed previously, corporate tax, zakat, and bankruptcy costs have influence on optimal capital structure decision. Thus, in order to investigate the consistency between theoretical hypotheses and empirical facts on optimal capital structure choices, the empirical method of analysis will utilize panel data with pooled ordinary least square (OLS). However, the motivation behind using the panel data for the analysis is because of possible information and estimation efficiencygains (Gujarati, 2004).

Furthermore, the basic empirical model is a panel data regression of the firm's leverage against the corporate tax and other explanatory variables. In general, the empirical model is expressed as;

$$
\begin{gathered}
\mathrm{LEV}_{i t}=\alpha_{0 i}+\alpha_{1} \mathrm{Z}+\alpha_{2} \mathrm{CT}_{i t}+\alpha_{3} \mathrm{SIZE}_{i t}+\alpha_{4} \mathrm{BC}_{i t}+\alpha_{5} \mathrm{ROA}_{i t}+\alpha_{6} \mathrm{TA}_{i t}+ \\
\varepsilon_{i t}
\end{gathered}
$$

where LEV is leverage, $\mathrm{Z}$ is zakat payment, $\mathrm{CT}$ is corporate tax, SIZE is firm size, BC is bankruptcy cost, TA is tangible assets, and is $\varepsilon_{\text {it }}$ error term. 
Since the estimation for equation (12) uses the panel data and relates to individual firm, there is subject to be heterogeneity in these firms over time. In order to take such heterogeneity explicitly in our estimation procedure, several assumptions about the intercept and the error term have to be made.

\section{The Within-Groups Fixed Effects Model}

The Fixed Effect estimator proceeds by removing unobserved effect $\lambda_{i}$ (the source of the problem) from the model, and then running OLS on the resulting model. Therefore, we can rewrite equation (12) as:

$$
\begin{aligned}
\operatorname{Lev}_{i t}-\overline{\operatorname{Lev}}_{i t}= & \alpha_{0}-\alpha_{0}+\lambda_{i}-\bar{\lambda}_{i}+\alpha_{1}\left(Z_{1 i t}-\bar{Z}_{1 i}\right)+\alpha_{2}\left(C T_{1 i t}-\right. \\
& \left.\overline{C T}_{1 i}\right)+\alpha_{3}\left(\operatorname{SIZE}_{1 i t}-\overline{\operatorname{SIZE}}_{1 i}\right)+\alpha_{4}\left(B C_{1 i t}-\overline{B C}_{1 i}\right)+ \\
& \alpha_{5}\left(R O A-\overline{R O A}_{1 i}\right)+\alpha_{6}\left(T A_{1 i t}-\overline{T A}_{1 i}\right)+u_{i t}
\end{aligned}
$$

Since the fixed effect estimator relies on the within (or time series) variations, the effects of variables that do not change through time cannot be identified.

\section{The Random Effects Model}

In this model, the individual specific effect is characterized as random. By assuming the intercept value for an individual firm as:

$$
\alpha_{0 i}=\alpha_{0}+\mathrm{u}_{i 2}
$$

where $\mathrm{u}_{i 2}$ is a random error term with a mean value of zero and variance of $\sigma_{\lambda}^{2}$. Substituting equation (14) into (12), we obtain:

$$
\begin{aligned}
\mathrm{LEV}_{i t}= & \alpha_{0 i}+\alpha_{1} \mathrm{Z}_{i t}+\alpha_{2} \mathrm{CT}_{i t}+\alpha_{3} \mathrm{SIZE}_{i t}+\alpha_{4} \mathrm{BC}_{i t}+\alpha_{5} \mathrm{ROA}_{i t}+\alpha_{6} \mathrm{TA}_{i t} \\
& +\varepsilon_{i t}
\end{aligned}
$$

where the error term $\varepsilon_{i t}$ consists of two components $\lambda_{i}$ which is the cross section or individual specific, error component and $u_{i t}$ which is the combined time series and cross section error component.

If the error terms of firms at two different points in time are correlated, the correlation coefficient, corr $\left(\mathrm{w}_{i}, \mathrm{w}_{i s}\right)$ is as follows:

$$
\text { (Corr (wit, wis) } \left.=\frac{\sigma^{2} u_{2}}{\sigma^{2} u_{2}+\sigma^{2} u_{1}}\right)
$$


From equation (16), two features of the correlation coefficient can be highlighted. Firstly, the value of correlation between error terms at two different times remains the same for any given cross sectional unit. Secondly, the correlation structure given in equation (16) remains the same for all cross sectional unit. Hence, by employing the OLS estimation procedure, the resulting estimators will be inefficient. Therefore, the most appropriate method is the method of generalized least square (GLS). At this point, however, the equations are linked by the disturbances.

\section{The Two Way Fixed Effects Model}

A common specification in panel data models is the unbalanced twoway fixed effects model which includes a set of fixed effects for primary units indexed by $i=1, \ldots, N$ and secondary units indexed by $j=1, \ldots$, J. Thus, there are $\mathrm{N}$ primary units and J secondary units. The model is defined by:

$$
\begin{aligned}
\mathrm{LEV}_{i t}= & \alpha_{0}+\alpha_{1} \mathrm{D}_{1 i}+\ldots .+\alpha_{\mathrm{k}} \mathrm{D}_{\mathrm{k} i}+\gamma_{0}+\gamma_{1} \mathrm{D}_{1 t}+\ldots \ldots \ldots+\gamma_{k} \mathrm{D}_{\mathrm{k} t} \\
& +\beta_{1} \mathrm{Z}_{i t}+\beta_{2} \mathrm{CT}_{i t}+\beta_{3} \mathrm{SIZE}_{i t}+\beta_{4} \mathrm{BC}_{i t}+\beta_{5} \mathrm{ROA}_{i t}+\beta_{6} \mathrm{TA}_{i t} \\
& +\varepsilon_{i t}
\end{aligned}
$$

Where the model includes both individual-specific affects $\alpha_{i}$ and period-specific effects $\gamma_{t}$.

\section{RESULTS AND ANALYSIS}

This section analyzes the estimation results for the pooled OLS model (model 1), random effect model (model 2), fixed effect model (model 3), fixed effect with robust standard error (model 4), OLS with hetero and serial correlation (model 5) and two way fixed effect (model 6). Generally, the $\mathrm{R}^{2}$ values are good enough, especially with two way fixed effect (0.96). The $p$-value is compared to the $F$ value, and the null hypotheses for the F-test are rejected. Therefore, the estimated coefficients for all variables (except the intercept and constant) differ from zero.

Furthermore, there are two basic tests to decide the best model. The first of these tests is the Breuch-Pagan test, and it is used to 
discriminate between the pooled model and the random effect model. However, the result shows that the $p$-value $<0.05$, reject $\mathrm{H} 0$. It means that the random effect model is more appropriate than OLS (pooled model). In other words there are individual specific effects in the data.

The second test that is commonly used in applied panel data analysis seeks to determine which is more appropriate: random or fixed effects. Since we have two estimators, one efficient under the null, but biased under the alternative, and another unbiased under both, we can use the Hausman specification test. However, the result shows that the $p$-value for the test is $<5 \%$, reject the null hypothesis. This indicates that the random effects model is not appropriate and that the fixed effects specification is to be preferred.

The first diagnostic check after estimation is multicollienarity check, detect by using variance inflation factor (vif). If mean vif $>5$, there is a multicollienarity problem. However, the result shows that there is no multicollienarity in the model since mean vif $<5$. The second diagnostic check is heteroskedasticity test using the Modified Wald Statistic for groupwise heteroskedasticity in the residuals of a fixed effect regression model (Greene, 2000). The result shows that the $p$ value is $<0.05$, reject the $\mathrm{H} 0$. This meanns that the variances are not constant (there is a heteroskedasticity problem). Then, the third diagnostic check is serial correlation test using Wooldridge test or a Lagram-M ultiplier test. The result shows that $p$-value is $<0.05$, reject the $\mathrm{HO}$. This means that there is a serial correlation problem and conclude the data does have first-order autocorrelation. Further, Hook (2012) suggested to use the OLS with heteroskedasticity and serial correlation robust standard error (robust cluster) to rectify the problem.

In line with the diagnostic check, it can be concluded that model 5 (OLS with hetero and serial correlation) is the best model in explaining the significant level of each explanatory variable. This model report the significant independent variables, namely zakat, corporate tax, and ROA. Moreover, the sign of two independent variables is consistent with the hypothesis, namely $Z$ and ROA.

Theoretically, one of determinant that determines the capital structure choice of firms is the effective tax rate. Thus, from the perspective of the static tradeoff theory, firms with higher taxable 
income should borrow more debt to take advantage of interest taxshield. In consequence, the effective tax rate and level of debt is positively correlated for firm value. Interestingly, the results from all the model as showed in table 3, reveals the negative correlation between corporate tax with leverage. However, this result is in line with M. Negash (2002) studied, which used 64 firms that were listed in the Johannesburg Stock Exchange (JSE) for the 1991-1998 period, he found a negative association between the tax rate variables and extent of leverage.

More interestingly, the empirical result proved that there is significant negative relationship between zakat and leverage. Thus, the results support the theoretical model that zakat would encourage firm to issue more equity than debt. In addition, this result also accordance with empirical study of Sanusi (2014) that zakat able to increase the equity financing by reducing the use of leverage. While, this study reveals that ROA as the measurement of profitability has a strong negative relationship with leverage. Myers (1984) suggests that companies seeking to reduce the costs of asymmetric information have a preference of funding resources (hierarchy of preference). Hence, companies would prefer using retained earnings firstly, then low-risk debt, high-risk debt, and as the last resource, new equity. Moreover, De Jong et al. (2008), Qian et al. (2009), De Jong et al. (2011), Kayo \& Kimura (2011), Guney et al. (2011), McMillan \& Camara (2012), Tongkong (2012), Mateev et al. (2013), and Islam \& Khandaker (2015) also found a similar result that ROA inversely correlated with leverage. 


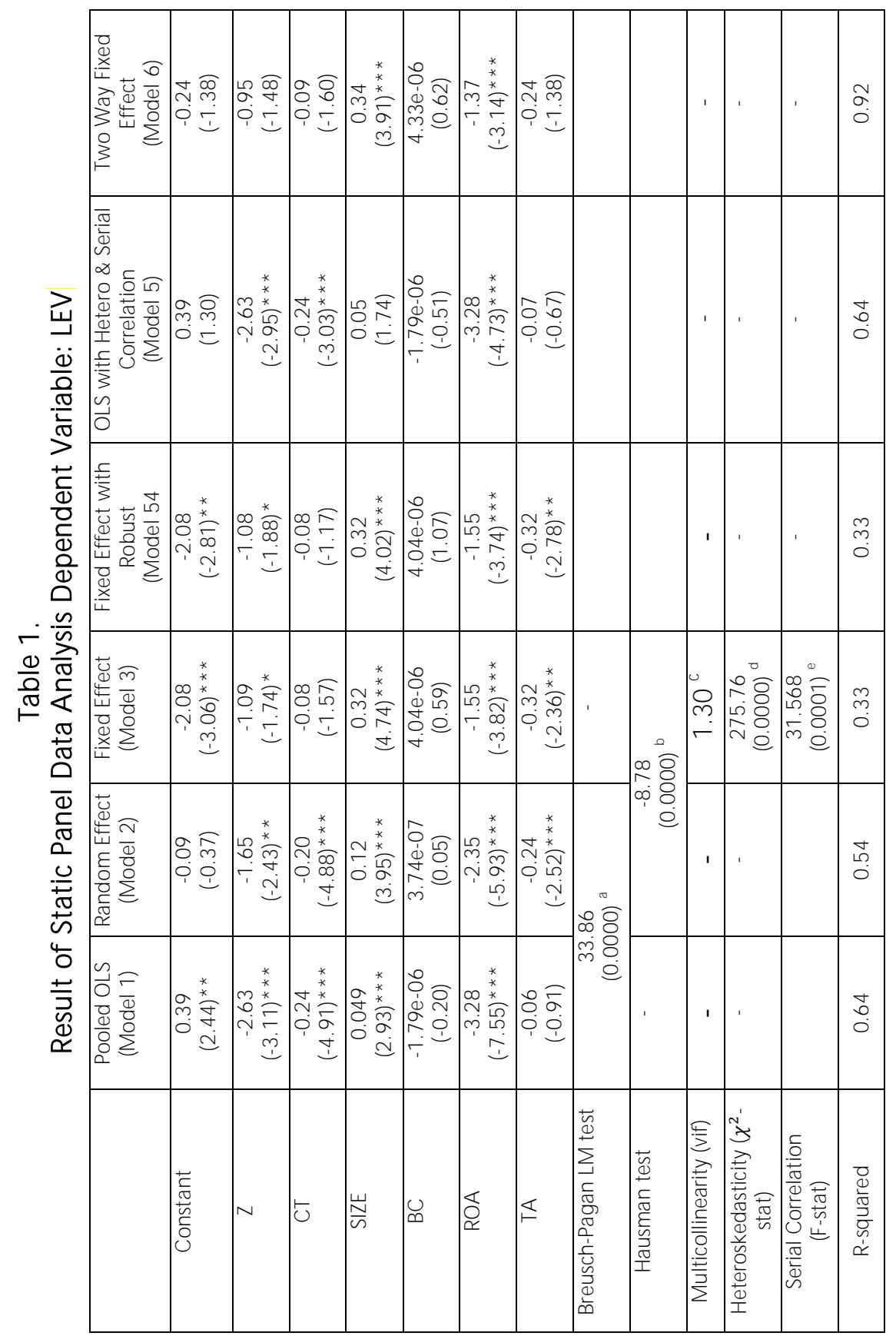


1. Figures in the parentheses are t-statistics, except for Breusch-Pagan LM test, Hausman test, Heteroskedasticity and Serial Correlation, which are p-values

2. *,** and $* * *$ indicate the respective $10 \%, 5 \%$ and $1 \%$ significance levels

3. a indicates the random effect model is more appropriate than OLS

4. $b$ indicates the fixed effect model better than the random effect model

5. c indicates no multicollinearity (vif $<5)$

6. $d$ indicates variances are not constant (heteroskedasticity problem)

7. e indicates serial correlation problem

\section{CONCLUSION AND RECOMMENDATION}

\subsection{Conclusion}

The emprical analysis investigates the panel data of 17 year firm leverage ratios for 14 firms which pay taxes as well zakat. The results shows that model 5 (OLS with hetero \& serial correlation) is the best model in explaining the significant level of each explanatory variable. However, the results prove that the zakat payment is an important determinant which is inversely related to firm leverage. The result in line with the comparative statics analysis which proved that the optimal level of debt is inversely related to the zakat payment. The question on whether zakat is a prior lead to an advantage or to a disadvantage for the utilization of debt financings by the firm has given slightly point of light. The managerial option policy is expected to reduce debt financings because they increase the current liabilities and alternatively issuing more equity in consequence of corporate zakat payment. In addition, it can strengthen the early notion that zakat may promote firms to issue an equity rather than debt as a result of "the zakat payment shield benefit".

\subsection{Recommendation}

As discussed earlier, financing with debt not only provides benefit from interest tax shield but aslo generates costs of debt such as the risk of bankruptcy as well as agency costs. However, this study has showed that the presence of zakat payment will motivate firm to prefer equity financing sources than debt financing sources. So that, by choosing the issue of equity as a source of financing, the firm will be able to reduce the risk of bankruptcy due to debt obligations. Thus, the firm also can decrease the cost of interest. However, the bankruptcy costs and interest costs should be allocated to other 
expenses that may improve the performance of the firm, such as expense for research and development as well as the cost for advertising and promotion. Ultimately, the increase of profits not only provide benefits to the owner of the company but also will raise the payment of zakat by the firms, which in turn contribute the benefits to the people who receive the zakat (shohibul maal) through the zakat institution. However, based on the evidence both theoretical model and empirical study in Malaysia. This study proposes to Indonesian government especially to be able consider zakat on business as part of tax deduction policy. Because it is not only beneficial for the business environment but also could improve the welfare of people in need. 


\section{REFERENCES}

Ahmad, Z. et al. (2012). Capital structure effect on firms performance - focusing on consumers and industrials sectors on malaysian firms. International Review of Business Research Papers, 8(5), 137-155.

Almeida, H. \& Campello, M. (2007). Financial constraints, asset tangibility, and corporate investment. The Review of Financial Studies, 20(5), 1429-1460.

Badawi, A. (2004). The 2005 budget speech: Introducing the supply bill (2005) in the Dewan Rakyat.

Bakar, N. B. A. (2007). A Zakat Accounting Standard (ZAS) for malaysian companies. The American Journal of Islamic Social Science, 24(4), 74-92.

Barakat, M., \& Rao, R, P. (2003). The role of taxes in capital structure: Evidence from taxed and non-taxed Arab economies (M unich Personal RePEc Achive - MPRA Paper No. 25472). Munich: University Library of M unich.

Besley, S., \& Brigham, E. F. (2003). Principles of finance $\left(2^{\text {nd }}\right.$ ed. $)$. USA: Thomson-Learning.

Booth, L., Aivazian, V., Demirguc-Kunt, A. \& Maksimovic, V. (2001). Capital structures in developing countries. The Journal of Finance, 56(1), 87-130.

Bradley, M., Jarrell, G., \& Kim, E. H. (1984). On the existence of an optimal capital structure: Theory and evidence. Journal of Finance, 39(3), 857-878.

Byoun, S. (2008). How and when do firms adjust their capital structure toward targets?. The Journal of Finance, 63(6), 3069-3096.

Castanias, R., (1983). Bankruptcy risk and optimal capital structure. The Journal of Finance, 38(5), 1617-1635.

Dawood, M. H., Muostafa, E. I., \& El-Hennawi, M. S. (2011).The determinants of capital structure in listed egyptian corporations. Middle Eastern Finance and Economics, No.9, 3-29. 
Datta, R., Chowdhury, T. U., \& Mohajan, H. K. (2013). Reasses of capital structure theories. International Journal of Research in Computer Application \& Management, 3(10), 102-106.

DeAngelo, H. \& M asulis, R.W. (1980). Optimal capital structure under corporate and personal taxation. Journal of Financial Economics, 8(1), 3-29.

De Jong, Abe., Kabir, R. \& Nguyen, T.T. (2008). Capital structure around the world: The roles of firm- and country-specific determinants. Journal of Banking and Finance, 32(9), 1954-1969.

De Jong, Abe., Verbeek, M. \& Verwijmeren, P. (2011). Firms' debtequity decisions when the static tradeoff theory and the pecking order theory disagree. Journal of Banking and Finance, 35(5), 1303-1314.

Fama, E. F., \& French, K. R. (2002). Testing trade-off and pecking order predictions about dividends and debt. Review of Financial Studies, 15(1), 1-33.

Frank, M. Z., \& Goyal, V. K. (2009). Capital structure decisions: Which factors are reliably important? Financial Management, 38(1), 137.

Gaud P., Jani E., Hoesli M., \& Bender A. (2005). The capital structure of swiss companies: An empirical analysis using dynamic panel data. European Financial Management, 11(1), 51-69.

Givoly D., Hayn, C., Ofer, A. R. \& Sarig, O. (1992). Taxes and capital structure: Evidence from firms response to the tax reform act of 1986. The Review of Financial Studies, 5(2), 331-355.

Gleason, K. C., Mathur, L.K., \& M athur, I. (2000). The interrelationship between cultures, capital structure, and performance: Evidence from european retailers. Journals of Business Research, 50(2), 185-191.

Graham, J. R. (1996). Debt and the marginal tax rate. Journal of Financial Economics, 41(1), 41-73.

Graham, J. R., M. L. Lemmon, and J. S. Schallheim (1998). Debt, leases, taxes, and the endogeneity of corporate tax status. The Journal of Finance, 53(1), 131-162. 
Greene, W. (2000). Econometric analysis. Upper Saddle River, NJ: Prentice-Hall.

Gujarati. (2004). Basic econometrics (4 ${ }^{\text {th }}$ edition). The McGraw-Hill.

Guney, Y., Li, Ling \& Fairchild, R. (2011). The Relationship between product market competition and capital structure in chinese listed firms. International Review of Financial Analysis, 20(1), 4151.

Haugen, Robert A. \& Senbet, Lemma W. (1988). Bankruptcy and agency costs: Their significance to the theory of optimal capital structure. The Journal of Financial and Quantitative Analysis, 23(1), 27-38.

Hirota, S. (1999). Are corporate financing decisions different in Japan?: An empirical study on capital structure. Journal of the Japanese and International Economies, 13(3), 201-229.

Hook, Law Siong. (2012, November). Dynamic panel data. Paper presented at Panel Data Analysis Workshop, Universiti Sains M alaysia, 28-29 November 2012.

Huang, G., \& Song, F. M. (2006). The determinants of capital structure: Evidence from China. China Economic Review, 17(1), 1436.

Islam, S. Z., \& Khandaker, S. (2015). Firm leverage decisions: Does industry matter?. North American Journal of Economics and Finance, Vol. 31, 94-107.

Jensen, M. C., \& Meckling, W. (1976). Theory of the firm: Managerial behavior, agency costs and ownership structure. Journal of Financial Economics, 3(4), 305-360.

Jensen, M. C. (1986). Agency cost of free-cash-flow, corporate finance, and takeovers. American Economic Review, 76(2), 323329.

Kayo, Eduardo K. \& Kimura, Herbert (2011). Hierarchical determinants of capital structure. Journal of Banking \& Finance, 35(2), 358371.

Kraus, Alan and Litzenberg, R.H. (1973). A state-preference model of optimal financial leverage. Journal of Finance, 28(4), 911-922. 
Mateev, M., Poutziouris, P. \& Ivanov, K. (2013). On the determinants of SME capital structure in Central and Eastern Europe: A dynamic panel analysis. Research in International Business and Finance, 27(1), 28-51.

Mackie-Mason, J. (1990). Do taxes affect corporate financing decisions?. Journal of Finance, 45(5), 1471-1493.

McM illan, David G. \& Camara, Omar. (2012). Dynamic capital structure adjustment: US MNCS \& DCs. Journal of Multinational Financial Management, 22(5), 278-301.

Miller, M. (1977). Debt and taxes. The Journal of Finance, 32(2), 261275.

Modigliani, Franco \& M iller, Merton H. (1958). The cost of capital, corporation finance and the theory of investment. The American Economic Review, 48(3), 261-297.

Modigliani, F., \& Miller, M. H. (1963). corporate income taxes and the cost of capital: A correction. American Economic Review, 53(3), 433-443.

M yers, S. C. (1977). Determinants of corporate borrowing. Journal of Financial Economics, 5(2), 147-175.

Myers, S. C. (1984). The capital structure puzzle. Journal of Finance 39(3), 575-592.

Myers, S. C. (2001). Capital structure. Journal of Economics Perspective, 15(2), 81-102.

Negash, M. (2002). Corporate tax and capital structure: Some evidence and implications. Investment Analysts Journal, 31(56), 17-27.

Othman, H. J. M. (2013, October). Zakat and tax treatment. Paper presented at National Business Zakat Symposium 2013, Kuala Lumpur.

Overesch, M., \& Voeller, D., (2008). The impact of personal and corporation taxation on capital structure choices (Discussion Paper No.08-020). Mannheim: ZEW-Centre for European Economic Research. 
Psillaki, M., \& Daskalakis, N. (2008). Are the determinants of capital structure country or firms specific? Evidence from SMEs. Small Business Economics, 33(3), 319-333.

Qian, Y., Tian, Y. \& Wirjanto, T.S. (2009). Do chinese publicly listed companies adjust their capital structure toward a target level?. China Economic Review, 20(4), 662-676.

Rajan, R.G \& Zingales, L. (1995). What do we know about capital structure? Some evidence from international data. Journal of Finance, 50(5), 1421-1460.

Rasiah, D., \& Kim P. K. (2011). A theoretical review on the use of the static trade off theory, the pecking order theory and the agency cost theory of capital structure. International Research Journal of Finance and Economics, No. 63, 150-159

Sanusi, N. A. (2014). The dynamics of capital structure in the presence of zakat and corporate tax. International Journal of Islamic and Middle Eastern Finance and Management, 7(1), 89-111.

Shahid, M.A., Wasim. H. A., Khan. M.A. (2014). Analysis of determinants of capital structure: with special reference to indian listed non-financial companies in $\mathrm{S}$ and $\mathrm{P}$ CNX Nifty. Business Dimensions, 1(2), 147-155.

Scott, J. H. (1976). A theory of optimal capital structure. The Bell Journal of Economics and Management Science, 7(1), 33-54.

Sheikh, N. A., \& Wang, Z. (2011). Determinants of capital structure: An empirical study of firms in manufacturing industry of Pakistan. Managerial Finance, 37(2), 117-133.

Shyam Sunder, L. \& Myers, S.C. (1999). Testing static tradeoff against pecking order models of capital structure. Journal of Financial Economics, 51(2), 219-244.

Song, H. S. (2005). Capita structure determinants: an empiric al study of swedish companies (Electronic Working Paper Series No.25). Stockholm: Royal Institute of Technology, Centre of Excellence for Studies in Innovation and Science.

Tongkong, Supa (2012). Key factors influencing capital structure decision and its speed of adjustment of thai listed real estate 
companies. Procedia - Social and Behavioral Sciences, Vol. 40, 716-720.

Titman, S. \& Wessels, R. (1988). The determinants of capital structure choice. Journal of Finance, 43(1), 1-19.

Voutsinas, Konstantinos \& Werner, Richard A. (2011). Credit supply and corporate capital structure: Evidence from Japan. International Review of Financial Analysis, 20(5), 320-334. 